INDEPENDENT JOURNAL OF MANAGEMENT \& PRODUCTION (IJM\&P) http://www.ijmp.jor.br

v. 12, n. 2, March-April 2021 ISSN: 2236-269X

DOI: 10.14807/ijmp.v12i2.1321

\title{
CEOS' INFLUENCES ON THE STOCK PERFORMANCE ON COMPANIES
}

Maria Augusta Soares Machado IBMEC-RJ, Brazil E-mail: fuzzy-consultoria@hotmail.com

Ana Beatriz de Mello Moraes IBMEC-RJ, Brazil E-mail: ana.moraes@ibmec.edu.br

Alberto Jacobsen Fuzzy Consultoria Ltda, Brazil E-mail: fuzzy-consultoria@hotmail.com

André Machado Caldeira Fuzzy Consultoria Ltda, Brazil E-mail:amcaldeira@yahoo.com.br

Bruno Roberto Santos Fuzzy Consultoria Ltda, Brazil E-mail: bruno.roberto.2019@gmail.com

Submission: $3 / 30 / 2020$

Revision: 5/13/2020

Accept: 6/3/2020

\section{ABSTRACT}

Investors are not concerned with subjective internal measures, employees' satisfaction or internal policies regarding the CEO's evaluation and their compensation. For the investor, the most important aspect is the return of their investment. This paper focuses filling the gap left generically and quantitatively in evaluating the CEOSs influence on the stock performance on their companies during their management. The measurement of the CEOSs influence on the stock performance of the most important North American companies is this paper's proposal. Assuming an efficient market and observing these companies' stock performance during a specific period, it is possible to know with accuracy what these institutions created during the same period, as well as, expectation changes on their future profits. In this study, it was used some statistical tests described along the paper. This study demonstrated that, completely assume that the CEOSs of the main American companies were a determinant factor in the success of these corporations is a widely committed mistake. 
DOI: 10.14807/ijmp.v12i2.1321

Keywords: stock; performance; the investors' interests; dividends; adjustment

\section{INTRODUCTION}

Intellectual capital has recently obtained a growing recognition as the great assets of companies and economies. "While during a time the main production factor was land and latter on capital... Today the main factor is man on its own, in other words, his knowledge". Pope John Paul II (1991). Centesimus Annus.

Great company leaders are continuously in evidence on newspapers, magazines and news. Their leadership recognition is enhanced as are their remuneration. Besides these leaders' attributed importance, another disturbing characteristic of this phenomenon is the emphasis placed on how their leadership influence companies $\mathrm{X}, \mathrm{Y}$ and $\mathrm{Z}$ to become references in the market. Nevertheless, few questions should be inquired:

- Was company X really instigated by its superior leadership or was it predestined to succeed simply because its products were greater than the competitions'?

- Should Y Company's growth be attributed to its superior leadership or in fact its growth is due to the widespread difficulty faced by the competition?

- Was the Z pharmaceutical company really stimulated by its superior leadership or its performance should be really accredited to its researchers for they were capable of developing new drugs?

Regardless of a superior leadership, in the three examples above, those companies could have prospered, for their success is a result of independent factors, regardless of leadership. As a result, an opportunity to develop studies that aim the measurement of these leaders' importance to the companies arises. Nonetheless, many prior researches subjectively analyzed the Chief Executive Officers' (CEO) performance. According to Silva (2004, p. 87-102) until the present moment most developed works (Newman 2001; Tyler and Biggs 2001; Lear 1999) ${ }^{1}$; Ittner, 1997; Verespej, 1994; Longenecker and Goia 1988; Goldstein 1985) displayed speculative CEO evaluation methods and discussed the relation between salary and performance disregarding the financial aspect. These leaders' financial (investor's perspective) influence has been neglected till the present moment.

${ }^{1}$ Cf. other references to the topic, Ittner, 1997; Verespej, 1994; Longenecker and Goia 1988; Goldstein 1985 
INDEPENDENT JOURNAL OF MANAGEMENT \& PRODUCTION (IJM\&P)

http://www.ijmp.jor.br

v. 12, n. 2, March-April 2021

ISSN: $2236-269 X$

DOI: $10.14807 /$ ijmp.v12i2.1321

De Matos (2001, p. 3) affirms that the investors' main interest is the valuation of their assets. Investors are not concerned with subjective internal measures, employees' satisfaction or internal policies regarding the CEOSs evaluation and their compensation. For the investor, the most important aspect is the return of their investment.

Considering the previous paragraph true, the following can be stated: No other work has exclusively studied the CEOSs influence from the stock holders' perspective, that is, no prior work attempted to quantify the CEOSs influence on the stock performance of their companies.

Thus, this work had the ambition of filling the gap left open by its predecessors, generically and quantitatively evaluating the CEOSs influence on the stock performance of their companies during their management. The measurement of the CEOSs influence on the stock performance of the most important North American companies was this paper's proposal.

Assuming an efficient market and observing these companies' stock performance during a specific period, it is possible to know with accuracy ${ }^{2}$ what these institutions created during the same period, as well as, expectation changes on their future profits. According to Brealey (2003, p. 60) this is possible because the most common value determination method is the discounted ${ }^{3}$ cash flow method, hence the market will price stocks according to the companies' current and future profits, in other words, any alteration in the company policies capable of changing its future profits will cause an impact on its stock value today.

\section{METHODOLOGY}

\subsection{The selection of a reference index}

An important part of this paper was the selection of which public companies will have their leadership evaluated. The first step was to determine which companies were the most representative in the economy or capital market; this research has been extensively performed by many institutions.

An important part of this study was the selection of which public companies had their leadership evaluated. The first step was to determine which companies were the most

\footnotetext{
${ }^{2}$ According to Peters $(1996$, p.5) in an efficient market all assets are evaluated according to the available information.

${ }^{3}$ According to Brealey and Myers (2003, p. 60) the discounted cash flow formula is the same as the present value's formula for any other assets after deducing the cash flows that may be gained in the capital market by an interest rate that represents the associated risk.
} 


\section{INDEPENDENT JOURNAL OF MANAGEMENT \& PRODUCTION (IJM\&P)}

http://www.ijmp.jor.br

v. 12, n. 2, March-April 2021

ISSN: 2236-269X

DOI: 10.14807/ijmp.v12i2.1321

representative in the economy or capital market; this research has been extensively performed by many institutions.

Companies and specialized institutions such as Dow Jones \& Company, Fundação Getúlio Vargas, JP Morgan, Standard \& Poors, as well as, stock exchanges such as Bovespa, developed methodologies in order to create different market indexes, as for example: Dax 30 from Frankfurt, FTSE 100 from London, Nikkei 225 from Tokio and Ibovespa from São Paulo. The objective of these indexes was to represent the performance of economies or specific sectors through the alteration of a stock "package".

There are various representative indexes in many significant economies; hence, the second step was the establishment of the most appropriate market indexes to test the hypothesis of this work.

Since this was the first study to tests the hypothesis of CEOs from large companies as essential factors in their companies' stock performance, an analysis of the world's largest economy, the United States, is understandable. The American stock market is the most developed in the world; consequently the largest and most representative companies have their stocks negotiated there (regardless of the criterion, Marker Value, Accounting Value, Sales Price, Revenues and Profits among others).

After the country selection and which companies to analyze, it still remained to choose the most adequate index for this research, for the American economy is represented by many indexes: Wilshire 5000, Russel 2000, S\&P 500, Nasdaq, Dow Jones Industrial Average.

The Dow Jones Industrial Average index was chosen for many reasons; first, this index is an exception among all other indexes because it has a strict components selection process regulation. The components of the Dow Jones Industrial Average were selected by "The Wall Street Journal” editors. There weren't any pre-established criteria except for their headquarters to be stationed in the United States ${ }^{4}$.

The second motive was that according to the Dow Jones \& Company ${ }^{5}$ the companies included in this index must be recognized as leaders in their industries and always pass through a severe analysis before their inclusion.

\footnotetext{
${ }^{4}$ More details on the index methodology may be found on the Dow Jones \& Company website: Available at:

<http://www.djindexes.com/mdsidx/index.cfm?event=showAvgMethod>. Accessed on: $13^{\text {th }}$ of October of 2019.

5 Dow Jones \& company. Available at: <http://www.djindexes.com/jsp/avgMethod.jsp>. Accessed on: $27^{\text {th }}$ of October of 2019
} 
INDEPENDENT JOURNAL OF MANAGEMENT \& PRODUCTION (IJM\&P)

http://www.ijmp.jor.br

v. 12, n. 2, March-April 2021

ISSN: 2236-269X

DOI: $10.14807 /$ ijmp.v12i2.1321

The third positive characteristic of the Dow Jones Industrial Average index is the maintenance of its components. Unlike other market indexes the companies that compose the DJIA are rarely changed. Modifications only occur after the announcement of a drastic ${ }^{6}$ event involving one of the companies that compose the index.

The only negative aspect that could be pointed out against the use of the Dow Jones Industrial Average index in this study was that, it is only composed by thirty companies. On the other hand, according to the Dow Jones \& Company on June of 2003, the DJIA represented $29 \%^{7}$ of all that could be invested in the American market, besides daily appearing in most papers around the world, in the news throughout the globe, it is often transmitted during the day in many television networks and financial websites. The Dow Jones agency also affirms ${ }^{8}$ that "even though there are many market indexes, the DJIA remains as the one instinctively checked by professionals during the day”.

\subsection{Data Gathering}

At this point it's necessary to know which companies constituted the Dow Jones Industrial Average index on September $28^{\text {th }}$ of 2019. This is a public domain information, available in many publications, constantly transmitted throughout the day by television networks, websites ${ }^{9}$, or even still, in the Dow Jones \& Company website there is a document with the historical composition of the DJIA ${ }^{10}$ since its establishment on the $3^{\text {rd }}$ of July of 1884

\footnotetext{
${ }^{6}$ Fusions and acquisitions, changes in the Core Business are examples of drastic events capable of justifying such alterations. Available at: <http://www.djindexes.com/jsp/avgMethod.jsp $>$. Accessed on: $27^{\text {th }}$ of October of 2019.

${ }^{7}$ Dow Jones \& Company. Available at <http://www.djindexes.com/jsp/avgKeyBene.jsp> Accessed on: $9^{\text {th }}$ of October of 2019.

8 Dow $\quad$ J Jones Company. Available at: $<$ http://www.djindexes.com/mdsidx/index.cfm?event=showAvgBenefits>. Accessed on: $13^{\text {th }}$ of October of 2019.

${ }^{9}$ Few sites were these information may be found:

- Yahoo Finance. Available at: <http://finance.yahoo.com/q/cp?s=^DJl>. Accessed on: $13^{\text {th }}$ of October of 2019.

- Bloomberg. Available at: <http://www.bloomberg.com/markets/stocks/movers_index_dow.html> Accessed on: $13^{\text {th }}$ of October of 2014.

- Dow Jones \& Company. Dow Jones Indexes. Available at: $<$ http://www.djindexes.com/mdsidx/index.cfm?event=showComponentWeights\&rptsymbol=DJI\&sit emapid=1>. Accessed on: $13^{\text {th }}$ of October of 2019.

10 Dow Jones \& Company. Available at http://www.djindexes.com/downloads/DJIA_Hist_Comp.pdf Accesses on 27th of September of 2019.
} 
ISSN: 2236-269X

DOI: $10.14807 /$ ijmp.v12i2.1321

till its latest change on April the $8^{\text {th }}$ of 2019. According to this reference, on September $28^{\text {th }}$ of 2014 the DJIA was composed by the following companies (Table 1):

Table 1: Dow Jones Average Index

\begin{tabular}{|ll|}
\hline Name of the Company & Negotiation Code \\
\hline Alcoa & AA \\
Altria Group & MO \\
American International Group & AIG \\
American Express & AXP \\
Boeing & BA \\
Caterpilar & CAT \\
Citigroup & C \\
Coca Cola & KO \\
DuPont & DD \\
Exxom Mobile & XOM \\
General Eletric & GE \\
General Motors & GM \\
Hewllet Packard & HPQ \\
Home Depot & HD \\
Honeywell International & HON \\
IBM & IBM \\
Intel & INTC \\
Johnson \& Johnson & JNJ \\
JP Morgan Chase & JPM \\
Mc Donald's & MCD \\
Merck & MRK \\
Microsoft & MSFT \\
SBC Communications & SBC \\
3M & MMM \\
United Technologies & UTC \\
Pfizer & PFE \\
Procter \& Gamble & PG \\
Verizon & VZ \\
Wall Mart & WMT \\
Walt Disney Company & DIS \\
\hline
\end{tabular}

Now that all of the companies' names and are their respective CEOs are known, the date in which they assumed position remains to be disclosed. Different methods were employed to obtain these data: initially it was necessary to access the websites of the thirty companies and the Yahoo Finance ${ }^{11}$ website was used to obtain their addresses.

It was necessary to access the Websites and find the leadership pages from this point forward. Some of these companies shared the desired information; others presented in a fragmented manner or simply didn’t display any reference to it's leadership. The partners' pages were accessed and e-mails were written or request forms were filled, with the inquired

\footnotetext{
${ }^{11}$ Yahoo. Yahoo Finance. Available at: <http://finance.yahoo.com/?u>. Accessed on: 10th of October of 2019.
} 
INDEPENDENT JOURNAL OF MANAGEMENT \& PRODUCTION (IJM\&P)

http://www.ijmp.jor.br

v. 12, n. 2, March-April 2021

ISSN: 2236-269X

DOI: $10.14807 / i j m p . v 12 i 2.1321$

information, in the websites of the companies that didn't offer the necessary data on leadership.

The summary of this research ${ }^{12}$ is shown on the table 2 .

Table 2: Name of the CEOSs and the date they assumed their position

\begin{tabular}{|c|c|c|}
\hline Company & Name of the CEO & Assumed position on \\
\hline Alcoa & Alain J. Belda & $1^{\text {st }}$ of January 2001 \\
\hline Altria Group & Louis C. Camilleri & $25^{\text {th }}$ of April 2002 \\
\hline American International Group & Maurice R. Greenberg & 1967 \\
\hline American Express & Kenneth I. Chenault & $1^{\text {st }}$ of April 2001 \\
\hline Boeing & Harry C. Stonecipher & $1^{\text {st }}$ of December 2003 \\
\hline Caterpilar & James W Owens & $1^{\text {st }}$ of February 2004 \\
\hline Citigroup & Charles Prince & $8^{\text {th }}$ of September 2002 \\
\hline Coca Cola & E.Neville Isdell & $1^{\text {st }}$ of June 2004 \\
\hline DuPont & Chad Holliday Jr & $1^{\text {st }}$ of January 1999 \\
\hline Exxom Mobile & Lee R. Raymond & $1^{\text {st }}$ of April 1993 \\
\hline GE & Jeffrey R. Immelt & $7^{\text {th }}$ of September 2001 \\
\hline GM & Rick Wagoner & $1^{\text {st }}$ of May 2003 \\
\hline Hewllet Packard & Carly Fiorina & $1^{\text {st }}$ of July 1999 \\
\hline Home Depot & Robert L. Nardelli & $1^{\text {st }}$ of December 2000 \\
\hline Honeywell International & David M. Cote & $1^{\text {st }}$ of February 2001 \\
\hline IBM & Samuel J. Palmisano & $1^{\text {st }}$ of March 2002 \\
\hline Intel & Craig R. Barrett & $26^{\text {th }}$ of March 1998 \\
\hline Johnson \& Johnson & William C. Weldon & $1^{\text {st }}$ of April 2002 \\
\hline JP Morgan Chase & William B. Harrison, Jr. & $1^{\text {st }}$ of December 2000 \\
\hline Mc Donald's & Charlie Bell & $19^{\text {th }}$ of April 2004 \\
\hline Merck & Raymond V. Gilmartin & $1^{\text {st }}$ of June 1994 \\
\hline Microsoft & Steve. Ballmer & $1^{\text {st }}$ of January 2000 \\
\hline SBC Communications & Edward E. Whitacre Jr & $1^{\text {st }}$ of January 1990 \\
\hline $3 \mathrm{M}$ & W. James Mcnerney, Jr. & $1^{\text {st }}$ of January 2001 \\
\hline United Technologies & George. David & $1^{\text {st }}$ of April 1994 \\
\hline Pfizer & Hank McKinnell & $1^{\text {st }}$ of January 2001 \\
\hline Procter \& Gamble & A.G Lafley & $8^{\text {th }}$ of June 2000 \\
\hline Verizon & Ivan Seidenberg & $1^{\text {st }}$ of April 2002 \\
\hline Wall Mart & Lee Scott & $14^{\text {th }}$ of January 2000 \\
\hline Walt Disney Company & Michael D. Eisner & $1^{\text {st }}$ of September 1984 \\
\hline
\end{tabular}

Since the market index was chosen, the names of the companies and their respective CEOSs were known, to construct the tests two information were still missing:

${ }^{12}$ The website of the American International Group did not inform the date their current CEO assumed position. As indicated above, an e-mail was sent inquiring this information and the company refused to answer, the last alternative was a phone call to the partners' section and the same information was given. 
- The historical series adjusted by splits ${ }^{13}$ and dividends for a period of three years ${ }^{14}$, previous and posterior to the CEOs change for each one of the companies.

- The DJIA historical series for a period of three years prior to the oldest CEO change (Michael D. Einsner on the $1^{\text {st }}$ of September of 1984). Hence it was necessary to obtain a complete series since the $1^{\text {st }}$ of September of 1981.

The Yahoo Finance ${ }^{15}$ Website data base was used to obtain these data and other information including daily opening, maximum, minimum, closing and closing adjusted by splits and dividends, for all companies.

Since the used data was adjusted by splits and dividends ${ }^{16}$, based on prices from $19^{\text {th }}$ of October of 2019, a problem occurred with three of the twenty nine series. The stock historical series adjusted by splits and dividends for Exxom Mobile, SBC Communications and Walt Disney Company shows values around a few cents of the dollar, thus the estimated returns for these stocks achieved imprecise values ${ }^{17}$. These companies faced this problem for two reasons:

1. These companies uphold a good history of dividends ${ }^{18}$ paid to stock holders; therefore it was imperative to make constant adjustments to their historical series.

\footnotetext{
${ }^{13}$ According to the American law, a Split is an event that needs to be approved by the stock holders and board of directors. It's an event that increases the number of stocks by dividing each stock by a smaller amount of stocks. When it occurs the market prices for these stocks fall proportionally to the number in which the division was made.

${ }^{14}$ Among the thirty companies that compose the DJIA, there were nine cases of CEO change in less the three years, thus, for these nine companies there aren't any dada for the years subsequent the last CEO change. Hence, the series prior and posterior to a CEO change will be asymmetrical for these companies.

${ }^{15}$ The thirty companies' dividends history can be accessed filling the company's negotiation code at the end of the link. Yahoo. Yahoo Finance at http://finance.yahoo.com/q/hp?s=> Accesses on $19^{\text {th }}$ of October of 2019. i.e. to access General Motors' dada (negotiation code GM) the following link should be accessed: http://finance.yahoo.com/q/hp?s=gm. Yahoo. Yahoo Finance. Available on $19^{\text {th }}$ of October of 2019.

${ }^{16}$ The series adjusted by "splits" and dividends will be used, for they are the ones that trully demonstrate the stock holders real return.

17 The greatest problem was in the oldest part of the series.

${ }^{18} \mathrm{~A}$ good history of dividends is when companies have a clear dividends distribution policy, as well as, a good profit percentage distribution history, or in other words, a high "pay out ratio". According to Matos
} 
DOI: $10.14807 /$ ijmp.v12i2.1321

2. In the three cases, the last CEO change took place ten years earlier, increasing the effects of the constant dividends adjustment.

The problem above was solved by manually modifying the calculus base (closing on the $19^{\text {th }}$ of October 2019) for three exact years after the CEO alteration, for there was ${ }^{19}$ a closing series and a dividends history for each one of the companies.

\subsection{Data Treatment}

As mentioned previously, this study's main idea was the analysis of the relevance of CEOs on the stock performance of the most important American companies.

A possible hypothesis to establish if the CEOs were really determinant in the companies' success was to measure if the average return of the selected companies' stock varies when their CEOs were changed, in other words, test if the stock’s movement tendencies change when these companies have their leadership altered.

Before carrying through with the analysis a problem needs to be solved; stocks prices vary according to economic cycles and he perception of the economy's future. Thus, the stocks' prices tendencies are influenced by macroeconomic aspects, in other words, stock prices are influenced by systematic risk perceptions.

The macroeconomic effects must be detached from the microeconomic ones in order to observe the real performance of each companies' stock without the macroeconomic effects and thus analyze the CEOs' real relevance in the stock's performance, that is, its essential to know the stocks performance regardless of the market index variation. Three stages must be attained to achieve this goal:

The first step was to create a daily return series for the desired period for each one of the analyzed companies based on the closing historical series adjusted by splits and dividends, as well as, create a daily return series for the same period based on the DJIA's historical series.

After the creation of the companies' daily return series and the DJIA index daily return series, for the same period, the second step would be the creation of a return series with daily

(2001, p. 97) during most of the twentieth century corporations used dividends as their main tool to distribute the excess of liquidity to their stock holders.

${ }^{19}$ These companies dividends history can be accessed filling the company's negotiation code at the end of the link. Yahoo. Yahoo Finance at http://finance.yahoo.com/q/hp?s=Accesses on $19^{\text {th }}$ of October of 2019. Example: To obtain the dada for SBS Communications (negotiation code SBS) the following address should be accessed. http://finance.yahoo.com/q/hp?s=sbs. 
DOI: 10.14807/ijmp.v12i2.1321

returns discounted by the DJIA index's daily return, in other words, for the selected period, a excess return series with daily is being created for each company. It can also be affirmed that companies’ daily alphas ${ }^{20}$ series were being created.

The last stage was the definition of a base ${ }^{21}$ and then create, for each company, a historical closing series deduced by splits, dividends and the DJIA.

\subsection{Testing the Hypothesis}

This study has tested if the CEOs of the main American companies have significant influence on their company's stock return during their administration. To evaluate the CEOs influence on the return of their stock time series two periods has been used. These time series refer to the periods before and after the current CEO in each one of the companies.

From this point forward this paper had continued from the following premise: If a CEO change was capable of causing variations in the series' outcome during the periods constituted by the prior to and posterior moments of the Chiefs change. This will demonstrate that, in these cases, the CEOs had significant influence on the stocks' return, otherwise, the CEOs were not an important tool in their performances.

This study has tested in two ways the hypothesis that a CEO change causes a significant alteration on their companies' stock return. First, through a test called the Chow ${ }^{22}$ breakpoint test. The objective of this test is to generate $\mathrm{N}$ regressions for $\mathrm{N}$ sub-periods and verify if there is any significant difference among the estimated equations. A significant difference indicates a breakpoint.

The companies' stock return time series and the DJIA historical returns series' (for a period of six years, divided into two sub-periods, three of these years were prior to the CEO change and the other three were subsequent to the alteration) it was used with the aid of the Chow's breakpoint test to analyze the hypothesis proposed by this study.

\footnotetext{
${ }^{20}$ According to Gastineau (1996, p. 16) Alpha is the average of the return's bias for a specific assets in relation to a benchmark. The excess of return is also known as Jensen Measure Gastineau (1996, p. 162).

${ }^{21}$ The base used in this work is 100.

22 "Chow breakpoint test"
} 
DOI: $10.14807 /$ ijmp.v12i2.1321

The estimated equations were simple regressions where the dependent variables were the stock's return for the periods and the independent variables were Dow Jones Industrial Average Index return for the same period.

Two different results were expected after the Chow's breakpoint test :

1. Companies that presented a breakpoint in their alphas daily series after a CEO change.

2. Companies where there was no breakpoint in their alphas daily return series after a CEO change.

The results analysis were proceeded as follows: There are reasons to believe that in the case of companies, which presented a breakpoint a change of CEO modified the course of their stocks. There weren't any reasons to believe that a CEO change was a relevant factor on the stock performance of the companies that didn't present a breakpoint. In this aspect there were two possible results:

1. Companies with an alteration performance of their stocks;

2. Companies in which there was no change in the performance of their stocks.

Since there were two possible results, it was affirmed that the results had a binomial ${ }^{23}$, distribution, thus, a binomial test may be estimated in other to verify if in the general context of the big American corporations their CEOs do in fact deserve all the importance that has been attributed to them in the last few years.

The second method, to test if the CEOs of large companies significantly influence the return of their stocks, is a tendency test to verify the stock's daily excess return and then, verify if there was a significant change in the series' tendency before and after the change of CEOs.

A comparison between the tendencies of the alphas series' before and after the CEO change will be carried through the T student test for a single sample. In this case the tendencies of daily excess returns were provided by their average. The objective of the T student test is to discover if the average of the differences between the average of the alphas series prior to the CEO change and the average of the alphas series posterior to a CEO change equals zero ${ }^{24}$.

${ }^{23}$ According to Bonfaire (2001, p. 2), a normal distribution is also known as distribution or Bernoulli distribution.

${ }^{24}$ Mathematicaly: HO: $\alpha_{1}-\alpha_{2}=0$ 
ISSN: 2236-269X

DOI: $10.14807 /$ ijmp.v12i2.1321

\subsection{Mathematical Definitions}

The definitions for minimum square line, Chow test, binomial distribution and binomial test are listed below.

\subsubsection{Minimum Square Lines}

The minimum square line is like every line represented by a two variable equation (usually x and y). According to Spielgel (1997, p. 372), the minimum square line best approximates or adjusts the group of points $(\mathrm{x} 1, \mathrm{y} 1), \ldots,\left(\mathrm{xn}_{\mathrm{n}}, \mathrm{yn}^{2}\right)^{25}$. Its equation is:

$y=\alpha+\beta x$

By solving the following system, the $\alpha$ and $\beta$ constants can be defined:

$$
\begin{aligned}
& \sum y=a n+\beta \sum x \\
& \sum x y=a \sum n+\beta \sum x^{2}
\end{aligned}
$$

The $\alpha$ and $\beta$ values in equations 1.b and 1.c are given by the follow equations:

$$
\begin{gathered}
\alpha=\frac{\left(\sum y\right)\left(\sum x^{2}\right)-\left(\sum x\right)\left(\sum x y\right)}{n \sum x^{2}-\left(\sum x\right)^{2}} \\
\beta=\frac{n \sum x y-\left(\sum x\right)\left(\sum y\right)}{n \sum x^{2}-\left(\sum x\right)^{2}}
\end{gathered}
$$

\subsubsection{Chow's breakpoint test}

When there are doubts regarding the stability of estimated ${ }^{26}$ model's coefficients the Chow test should be applied, this test is frequently employed when it's perceived or there are reasons to believe that something relevant has occurred ${ }^{27}$ in the historical series in question ${ }^{28}$.

\footnotetext{
${ }^{25}$ In this paper he group of points, $x_{1}, x_{2} \ldots, x_{n}$ will be the DJIA returns and the group of points $y_{1}, y_{2} \ldots$ , $y_{n}$ will be the companies stock return.

${ }^{26}$ The estimated model in this work will be a simple regression.

${ }^{27}$ The CEO change is the relevant factor of this paper.

${ }^{28}$ In this paper, the series in question is the regression between the Companies Alphas and de DJIA...
} 
DOI: $10.14807 /$ ijmp.v12i2.1321

Suppose there is a series with $\mathrm{N}_{1}+\mathrm{N}_{2}$ observations and $\mathrm{K}$ parameters that allows the following model to be arranged:

$$
y=\beta x+\varepsilon
$$

Now, suppose that it is known that a great change has occurred in the period (change of CEO) and there are serious doubts that the model is the same for $\mathrm{N}_{1}$ observations and the last $\mathrm{N}_{2}$ observations. To answer this question using the chow test its necessary to build a model for the two series, one for the $\mathrm{N}_{1}$ observations and another one for the last $\mathrm{N}_{2}$ observations.

This model may be represented by the following regression:

$$
\begin{aligned}
& y_{1}=\beta_{1} x_{1}+\varepsilon_{1} \\
& y_{2}=\beta_{2} x_{2}+\varepsilon_{2}
\end{aligned}
$$

where:

$\mathrm{x}=$ Dow Jones Industrial Average daily returns

$\mathrm{y}=$ Stocks' daily returns

If $\beta_{1}=\beta_{2}$. In order to do so an UR (Unrestricted) model should be build.

$$
\left|\begin{array}{l}
y_{1} \\
y_{2}
\end{array}\right|=\left|\begin{array}{cc}
x_{1} & 0 \\
0 & x_{2}
\end{array}\right| \cdot\left|\begin{array}{l}
\beta \\
\beta_{2}
\end{array}\right|+\left|\begin{array}{l}
\varepsilon_{1} \\
\varepsilon_{2}
\end{array}\right|
$$

If the sum of the squared errors for model 2.b and 2.c are retained we can obtain:

$$
\frac{\left(R S S_{R}-R S S_{U R}\right) / K}{R S S_{U R} /\left(n_{1}+n_{2}-2 k\right)} \sim F K_{1} n_{1}+n_{2}-2 k
$$

Then, this model assumes an F distribution with a null equality hypothesis among the coefficients.

\subsubsection{Binomial Distribution}

A Binomial distribution may only assume two values: 0 and 1 . Such values are known as failure and success ${ }^{29}$.

${ }^{29}$ In this paper "success" means a breakpoint in the series, which was caused by the CEO change; and a "failure" means that there was no breakpoint in the series. 
DOI: $10.14807 /$ ijmp.v12i2.1321

Considering a sequence with $\mathrm{N}$ independent experiences ${ }^{30} \mathrm{E}_{1}, \mathrm{E}_{2}, \ldots$.., $\mathrm{E}_{\mathrm{n}}$, where each experience can only assume two possible variables: failure or success, and the outcome of a failure or a success in one of the Ei experiences does not effect the occurrence of others. This sequence of results $E_{1}, E_{2}, \ldots, E_{n}$ is called Bernoulli distribution.

Thus, the Bernoulli distribution may be written as:

$$
f(X)=\operatorname{Pr}(X=x)=\left\{\begin{array}{l}
\mathrm{p} \text { if } \mathrm{x}=1(\text { Success) } \\
\mathrm{q}=1-\mathrm{p} \text { if } \mathrm{x}=0 \text { (Failure) } \\
0 \text { for } \mathrm{x} \neq 0 \text { or } 1
\end{array}\right.
$$

\subsubsection{Proportion tests}

The values of the null and alternative hypotheses must be defined before the proportion test can be applied; they are denoted by $\mathrm{H}_{0}$ e $\mathrm{H}_{1}$ respectively.

As mentioned previously, the objective of this study was to test if the CEOs of large American companies were in fact decisive in the market performance of their stock. The Chow test was used to verify if the change of CEOs had an impact on each one of the companies separately. With a unilateral proportion test it will be possible to define if the proportion of companies that presented (or not) a breakpoint had an impact on the alphas for a specific $\mathrm{H}_{0}$.

The following proportions were adopted in this study:

- $\mathrm{H}_{0}=90 \%$,

- $\mathrm{H}_{1}=$ smaller than $\mathrm{H}_{0}$ respective proportions.

This means that it could be verified if a change of CEOs was not relevant for the stock performance in $90 \%$ of the cases. The unilateral proportions test is mathematically demonstrated by:

$$
\begin{aligned}
& \mathrm{H}_{0}: \mathrm{p}=\mathrm{p}_{0} \\
& \mathrm{H}_{1}: \mathrm{p}<\mathrm{p}_{0}
\end{aligned}
$$

The sample space $\mathrm{Z}$ is calculated by:

${ }^{30}$ There will be 30 experiments in this work (the results of the Chow test for each one of the companies that compose the DJIA). 
DOI: $10.14807 /$ ijmp.v12i2.1321

$$
Z=\frac{\hat{p}-p_{0}}{\sqrt{\frac{p_{0}-q_{0}}{n}}}
$$

The $\mathrm{Z}$ result is compared to the desired $\alpha$ level of significance. It can be concluded that:

- If $\mathrm{Z}<-\mathrm{Z}_{\alpha}$, rejects $\mathrm{H}_{0}$

- $\quad$ If $\mathrm{Z}>\mathrm{Z}_{\alpha}$, rejects $\mathrm{H}_{0}$

- If $|\mathrm{Z}|>-\mathrm{Z}_{\alpha / 2}$, rejects $\mathrm{H}_{0}$

\subsubsection{T student test for a sample}

The objective of the T student test, in this study, was to discover if the average of the difference between alphas series average prior to a CEO change by the alphas series average posterior to a CEO change are equal to zero.

In other words, the hypothesis tested was $\mathrm{HO}$ : $\alpha \mathrm{a}-\alpha \mathrm{p}=0$

The t statistics is calculated by:

$$
t=\frac{\bar{x}-\mu}{s(x) / \sqrt{n}},
$$

The level of significance ${ }^{31}$ in which $\mathrm{H} 0$ may be accepted or rejected is reveled after the $\mathrm{t}$ statistic is calculated.

\subsection{Methodology Restrictions}

There are restrictions in the proposed methodology; the first, as mentioned earlier, was the market efficiency assumption acknowledged in order to maintain consistency in this methodology. None the less, this hypothesis is common in the financial industry, according to Peters (1998, p.8) the market efficiency hypothesis has dominated the financial universe for at least thirty years, thus, Peters (1996, p. 13) affirms that for the past three decades, all theory and research on finance depends on this hypothesis.

Another restriction was the studied period after the CEO change, it was decided to establish a six year period. This restriction was imposed by the nature of the market, for if the period was longer there would be a larger number of companies whose CEOs had not assumed

\footnotetext{
${ }^{31}$ For the $t$ test: degree of freedom $=n-1$
} 
INDEPENDENT JOURNAL OF MANAGEMENT \& PRODUCTION (IJM\&P)

http://www.ijmp.jor.br

v. 12, n. 2, March-April 2021

ISSN: 2236-269X

DOI: $10.14807 /$ ijmp.v12i2.1321

their positions for a period superior to three years, on the other hand, a shorter period leads to less data for statistical tests.

\section{ANALYSIS OF THE HYPOTHESES TESTS}

The results of the tests described earlier are presented and interpreted in this section.

\subsection{The Chow breakpoint Test}

As mentioned before, this study's model can be represented by the regression $y=\alpha+$ $\beta \mathrm{x}$, thus, table 3 displays the alpha and beta coefficients, correlation and the determinant coefficient of all studied series ${ }^{32}$.

Table 3: Regression results

\begin{tabular}{|l|c|c|c|c|}
\hline \multirow{4}{*}{} & \multicolumn{4}{|c|}{ Regression } \\
\cline { 2 - 5 } & $\mathrm{A}$ & $\mathrm{B}$ & Correlation & $\mathrm{R}^{2}$ \\
\hline AA & -0.000003 & 0.2784 & 0.5651 & 0.3193 \\
MO & -0.000087 & 0.3625 & 0.7324 & 0.5364 \\
BA & -0.000079 & 0.1392 & 0.2618 & 0.0685 \\
CAT & 0.000040 & 0.3616 & 0.6366 & 0.4053 \\
C & -0.000461 & 0.4655 & 0.7330 & 0.5373 \\
KO & -0.000250 & 0.4172 & 0.7609 & 0.5789 \\
DD & -0.000021 & 0.4115 & 0.4772 & 0.2277 \\
XOM & 0.000368 & 0.2994 & 0.5552 & 0.3082 \\
GE & 0.000321 & 0.2456 & 0.4421 & 0.1954 \\
GM & 0.000056 & 0.4289 & 0.7455 & 0.5557 \\
HPQ & 0.000143 & 0.3680 & 0.6754 & 0.4561 \\
HD & 0.000282 & 0.1534 & 0.4405 & 0.1940 \\
HON & 0.000028 & 0.2709 & 0.5877 & 0.3453 \\
IBM & 0.000147 & 0.2754 & 0.6011 & 0.3613 \\
INTC & 0.000018 & 0.3003 & 0.5749 & 0.3305 \\
JNJ & 0.000440 & 0.1571 & 0.4496 & 0.2021 \\
JPM & -0.000028 & 0.3097 & 0.4238 & 0.1796 \\
MCD & 0.000109 & 0.3177 & 0.7001 & 0.4901 \\
MRK & -0.000080 & 0.2605 & 0.4041 & 0.1633 \\
MSFT & 0.000427 & 0.1925 & 0.4397 & 0.1933 \\
PFE & 0.000073 & 0.2742 & 0.5716 & 0.3267 \\
PG & 0.000123 & 0.2659 & 0.4610 & 0.2125 \\
SBC & -0.000162 & 0.3327 & 0.5966 & 0.3559 \\
MMM & 0.000076 & 0.2009 & 0.4691 & 0.2201 \\
UTX & -0.000085 & 0.4321 & 0.6183 & 0.3823 \\
VZ & 0.000202 & 0.2208 & 0.4678 & 0.2188 \\
WMT & -0.000151 & 0.3213 & 0.5831 & 0.3400 \\
DIS & 0.000481 & 0.1994 & 0.4157 & 0.1728 \\
\hline
\end{tabular}

32 The E-views 4.1 software was used to generate the regressions, alpha, beta, correlation and determination coefficients. 
DOI: $10.14807 /$ ijmp.v12i2.1321

Table 4, presents the Chow test, its F statistics and their respective log likelihood ratio ${ }^{33}$.

Table 4: Results of the "Chow breakpoint test"

\begin{tabular}{|l|c|c|}
\hline \multirow{2}{*}{} & \multicolumn{2}{|c|}{ Chow Test } \\
\cline { 2 - 3 } AA & F-statistic & Log likelihood ratio \\
AXP & 62.3082 & 120.0437 \\
MO & 28.2182 & 55.5512 \\
BA & 2.5625 & 5.1304 \\
CAT & 0.4776 & 0.9587 \\
C & 8.8368 & 17.5829 \\
KO & 14.7601 & 29.2768 \\
DD & 3.4032 & 6.8114 \\
XOM & 2.7824 & 5.5693 \\
GE & 0.9454 & 1.8947 \\
GM & 17.3469 & 34.3911 \\
HPQ & 1.0284 & 2.0624 \\
HD & 13.9516 & 27.7238 \\
HON & 9.4374 & 18.8049 \\
IBM & 32.9363 & 64.6424 \\
INTC & 46.0045 & 89.3933 \\
JNJ & 0.6585 & 1.3199 \\
JPM & 23.7688 & 46.8784 \\
MCD & 9.0186 & 17.9777 \\
MRK & 0.4622 & 0.4605 \\
MSFT & 11.1152 & 22.1272 \\
PFE & 40.8481 & 79.7686 \\
PG & 19.4854 & 38.5774 \\
SBC & 3.9509 & 7.9021 \\
MMM & 10.9095 & 21.7206 \\
UTX & 67.5759 & 129.7712 \\
VZ & 9.0283 & 17.9956 \\
WMT & 22.9687 & 45.3256 \\
DIS & 0.1037 & 0.2080 \\
\hline & 3.2233 & 6.4500 \\
\hline
\end{tabular}

It can be noticed from the F statistics results obtained through the Chow ${ }^{34}$ breakpoint test that:

1. With a $95 \%$ of confidence level no CEO change caused a breakpoint. In other words, it can be suggested, with a 95\% level of confidence, that the CEOSs influence on the price of stocks is not large enough to cause a tendency change on their stocks in comparison to the DJIA index.

2. Only one company presented a breakpoint with a $90 \%$ level of confidence, thus, it can be affirmed that a change of CEO in Wall Mart caused a breakpoint in its series.

${ }^{33}$ The Chow breakpoint tests were also estimated by the E-views 4.1 software.

${ }^{34}$ According to the results presented on table 3.1.2 
DOI: $10.14807 /$ ijmp.v12i2.1321

3. Only two CEO changes caused a breakpoint in their series with a $75 \%$ level of confidence. Besides Wall Mart, it can be suggested that the Altria Group also suffered a breakpoint with their CEO change at a 75\% level of confidence.

\subsubsection{Proportion test for the Chow tests results}

Based on the individual results of the Chow's Breakpoint test, the conclusions may be generalized in the form of a proportion test. The ideal would be a proportion test with a null hypothesis at $\mathrm{p}=1$, however, given the binomial test deficiency for $\mathrm{p}$ values near one, it is necessary to use smaller values for $\mathrm{p}$. Hence, it was tested at which level of confidence there will be no breakpoint in $90 \%$ of the cases ${ }^{35}$.

1. At a 95\% level of confidence, the Chow test results didn't present a breakpoint, thus, with a 95,28\% level of confidence it can be affirmed that in at least $90 \%$ of the cases there were no breakpoint.

2. Only one company presented a breakpoint with a $90 \%$ level of confidence the Chow test result, thus with $84.82 \%$ of confidence it can be affirmed that at least in $90 \%$ of cases were be no breakpoint.

\subsection{T student test for the stock's alphas}

As mentioned earlier, this study has used the T student test to discover if it is possible to make the following declaration: The average of the difference between the average of the alphas series prior to a CEO change and the average of the alphas series posterior to a CEO change equals zero.

Table 5 summarizes the results of the stock's average excess return for the periods before and after, as well as, their differences ${ }^{36}$.

Table 5: Alphas average prior and posterior to the CEO change and their differences

\begin{tabular}{|l|c|c|c|}
\hline & $\begin{array}{c}\text { Current Alphas } \\
\text { CEO }\end{array}$ & \multicolumn{1}{c|}{$\begin{array}{c}\text { Previous Alphas } \\
\text { CEO }\end{array}$} & Differences \\
AXP & 0.0005 & 0.0009 & 0.0004 \\
MO & 0.0005 & 0.0007 & 0.0002 \\
BA & 0.0002 & 0.0011 & 0.0010 \\
CAT & 0.0012 & -0.0004 & -0.0016 \\
C & 0.0007 & 0.0010 & 0.0004 \\
KO & 0.0006 & 0.0006 & 0.0000 \\
DD & -0.0022 & 0.0003 & 0.0025 \\
& -0.0001 & 0.0000 & 0.0001
\end{tabular}

${ }^{35} p=0.9$

${ }^{36}$ The alphas series, their average and their differences were calculated by the Microsoft Excel version 10.0.3506.0. 
DOI: $10.14807 /$ ijmp.v12i2.1321

\begin{tabular}{|l|c|c|c|} 
XOM & -0.0001 & 0.0007 & 0.0008 \\
GE & -0.0001 & 0.0006 & 0.0007 \\
GM & 0.0000 & -0.0006 & -0.0006 \\
HPQ & 0.0002 & 0.0003 & 0.0001 \\
HD & 0.0000 & 0.0005 & 0.0005 \\
HON & 0.0001 & 0.0002 & 0.0001 \\
IBM & 0.0000 & 0.0004 & 0.0004 \\
INTC & 0.0008 & 0.0010 & 0.0002 \\
JNJ & 0.0000 & 0.0005 & 0.0005 \\
JPM & 0.0004 & 0.0000 & -0.0004 \\
MCD & 0.0009 & 0.0002 & -0.0007 \\
MRK & 0.0008 & -0.0002 & -0.0011 \\
MSFT & 0.0006 & 0.0003 & -0.0003 \\
PFE & -0.0001 & 0.0007 & 0.0008 \\
PG & 0.0003 & 0.0015 & 0.0012 \\
SBC & 0.0005 & 0.0023 & 0.0018 \\
MMM & 0.0007 & 0.0004 & -0.0003 \\
UTX & 0.0010 & 0.0010 & 0.0000 \\
VZ & 0.0002 & 0.0001 & -0.0001 \\
WMT & 0.0003 & 0.0018 & 0.0015 \\
DIS & 0.0013 & -0.0001 & -0.0014 \\
\hline
\end{tabular}

Table 6 presents the characteristics of the series displayed on table 3.2.1, which were necessary to continue with the T student test. Table 3.2.2 also shows the T student (t statistic) result for the formulated hypothesis in its last line.

H0: $\alpha \mathrm{a}-\alpha \mathrm{p}=0$

Table 6 : The T Student test results for the differences between the alphas average

\begin{tabular}{|l|r|}
\hline \multicolumn{2}{|c|}{ T student test for a sample } \\
\hline Sample's average & 0.000230537 \\
H0 estimated average & 0 \\
Sample's standard deviation & 0.000892076 \\
Sample size & 29 \\
Degree of Freedom & 28 \\
T statistic & $\mathbf{1 . 3 9 1 6 7 6 0 1 2}$ \\
\hline
\end{tabular}

With $90 \%$ level of confidence, the results of the T statistic introduced on table 3.2.2 has permitted state that: there weren't indications that the CEOs of the companies that compose the DJIA may cause changes in their alphas' averages. In other words, with a $90 \%$ level of confidence it can be affirmed that the influence of a CEO on the their stocks' prices was not enough to cause a distortion on their returns' tendencies.

\subsection{Complementary tests for the series' volatility}

Complementary tests were estimated to analyze the series' standard deviation since previous tests do not indicate any evidence that a change of CEO caused alterations in the alphas’ average. 
INDEPENDENT JOURNAL OF MANAGEMENT \& PRODUCTION (IJM\&P)

http://www.ijmp.jor.br

v. 12, n. 2, March-April 2021

ISSN: 2236-269X

DOI: $10.14807 /$ ijmp.v12i2.1321

It has been tested that the series' tendencies do not change, if we could state that the series’ volatility didn't alter either, we could probably affirm that: the CEO change did not motivate any variation in the series' main characteristic.

\subsubsection{T Student test for the Standard deviation averages}

The inference, previously applied to the t statistic for the alphas' averages, was employed here, however, this time, the series' standard deviation was analyzed instead of the average excess of returns.

Table 7 sums up the Standard deviation results and the differences ${ }^{37}$ of the standard deviation of the excess of return series for the prior and posterior periods.

Table 7: Alphas' averages before and after the CEO change and their differences

\begin{tabular}{|c|c|c|c|}
\hline & $\begin{array}{c}\text { Current CEO } \\
\text { standard } \\
\text { Deviation }\end{array}$ & $\begin{array}{c}\text { Previous CEO } \\
\text { standard }\end{array}$ & Differences \\
\hline AA & 0.0173 & 0.0249 & 0.0076 \\
\hline AXP & 0.0154 & 0.0212 & 0.0058 \\
\hline MO & 0.0202 & 0.0252 & 0.0050 \\
\hline BA & 0.0104 & 0.0185 & 0.0082 \\
\hline CAT & 0.0117 & 0.0139 & 0.0021 \\
\hline $\mathrm{C}$ & 0.0105 & 0.0182 & 0.0077 \\
\hline $\mathrm{KO}$ & 0.0118 & 0.0140 & 0.0022 \\
\hline DD & 0.0199 & 0.0156 & -0.0042 \\
\hline XOM & 0.0100 & 0.0141 & 0.0041 \\
\hline GE & 0.0129 & 0.0165 & 0.0036 \\
\hline GM & 0.0112 & 0.0190 & 0.0078 \\
\hline HPQ & 0.0369 & 0.0221 & -0.0148 \\
\hline HD & 0.0176 & 0.0251 & 0.0075 \\
\hline $\mathrm{HON}$ & 0.0200 & 0.0248 & 0.0047 \\
\hline IBM & 0.0133 & 0.0231 & 0.0098 \\
\hline INTC & 0.0326 & 0.0218 & -0.0108 \\
\hline JNJ & 0.0130 & 0.0181 & 0.0051 \\
\hline JPM & 0.0210 & 0.0217 & 0.0007 \\
\hline MCD & 0.0117 & 0.0187 & 0.0071 \\
\hline MRK & 0.0129 & 0.0155 & 0.0026 \\
\hline MSFT & 0.0182 & 0.0251 & 0.0069 \\
\hline PFE & 0.0167 & 0.0225 & 0.0058 \\
\hline PG & 0.0179 & 0.0200 & 0.0022 \\
\hline SBC & 0.0126 & 0.0337 & 0.0211 \\
\hline MMM & 0.0108 & 0.0173 & 0.0066 \\
\hline UTX & 0.0113 & 0.0140 & 0.0027 \\
\hline VZ & 0.0164 & 0.0218 & 0.0054 \\
\hline WMT & 0.0207 & 0.0176 & -0.0031 \\
\hline DIS & 0.0158 & 0.0194 & 0.0037 \\
\hline
\end{tabular}

37 The alphas series, their Standard deviation and their differences were calculated by the Microsoft Excel version 10.0.3506.0 
Table 8 presents the series' necessary characteristics (displayed on table 3.2.1.) to estimate the $\mathrm{T}$ student test. The result of the $\mathrm{T}$ student ( $\mathrm{t}$ statistic) test for the formulated hypothesis is exposed on the last line of table 3.2.2.

H0: $\sigma \mathrm{a}-\sigma \mathrm{p}=0$

Table 8: T Student test results for the Alphas' Standard deviation differences

\begin{tabular}{|l|r|}
\hline \multicolumn{2}{|c|}{ Student test for a sample } \\
\hline Sample's average & 0.0039 \\
H0 estimated average & 0 \\
Sample's standard Deviation & 0.006403285 \\
Sample Size & 29 \\
Degree of Freedom & 28 \\
T Statistic & $\mathbf{3 . 2 7 7 3 7 7 4 0 4}$ \\
\hline
\end{tabular}

With a 99.75\% level of confidence the results on table 3.3.2 permits state that: there aren't evidences to suggest that a change of CEO in the companies that compose the DJIA may cause changes in their stocks' alphas standard deviation. In other words, it is possible to affirm with a 99.75\% level of confidence that the CEOSs influence on their stocks' price is not enough to cause a significant alteration in their companies' stocks standard deviation.

\subsubsection{F Test}

The CEOSs influence on the stock's tendencies were tested in two ways; first through the Chow Test, then, with the T test, nothing more reasonable than presenting a second test for the series' volatility. The result of the F test, for the standard deviations, is 0.876 .

The F test confirms the result of the previous test: With $99.75 \%$ level of confidence the F test enables the following statement : the CEOSs influence in their stocks' prices were not enough to cause significant changes in their companies' stocks standard deviation.

\section{CONCLUSIONS}

The developed study demonstrated that, completely assume that the CEOSs of the main American companies were a determinant factor in the success of these corporations is a widely committed mistake.

After an impartial study (free from any evaluation or subjective examination) on the Chief Executive Officers' influence on the stock performance of the thirty main public companies in the United States, it was concluded, based on strong statistical evidences and 
DOI: 10.14807/ijmp.v12i2.1321

quantitative methods of analysis on the time series related to the companies' 38 stocks performance that: The CEOSs of the companies that compose the Dow Jones Industrial Average index, for a period of six years, were not capable of significantly transforming these corporations as to observe their influence on the stocks' prices.

To explain this phenomenon few assumptions can be made: It's reasonable to assume that professionals with enough ability and experience to reach the position of a CEO in one of these large companies, when faced with the necessary data to make a decision, they would respond at the same manner or at least in a similar way. Another assumption was that, because these companies are large physically and financially and considered global leaders in their fields, the CEOSs have their roles minimized for their performance. Even though it was not this study's scope to find the reasons, it's possible that there are many other factors more relevant than leadership to the companies' performance. These assumptions are not mutually excluding, hence, one or more can be accepted as true.

Scientific methods suggest that common sense influenced by empirical conclusions often mentioned in works, articles, newspapers, magazines, network transmissions and among others, is in great part attributing untruthful and unjust credit to CEOSs. The common sense created a tradition where CEOSs were believed to be a great differential; hence the myth of their importance emerged. Their extraordinary salaries and space in the media and academic world are justified through the myth of their essential importance to the companies' results.

It was interesting to finally observe how this study had more general results to find endorsement in the work of contemporary philosophers such as Theodor Adorno and Martin Heidegger. These authors clearly criticize the contemporary world from the human perspective, describing men as being rapidly absorbed by the technical autonomous process, procedures these, which continually reduce the intervention and transformation power of human actions in general ${ }^{39}$.

Future analyses on the CEOSs importance to their companies' performance should be more rigorous and careful, for the results presented in this study contradict common sense;

${ }^{38}$ The total number of tests were: twenty-nine Chow tests, two T test, one $F$ test and one proportion test.

${ }^{39} \mathrm{Cf}$. as for this aspect, Martin Heidegger, Voträge und Aufsätze, Theodor Adorno and Max Horkheimer, Dialética do esclarecimento and Marco Casanova, Nada a caminho. 
DOI: 10.14807/ijmp.v12i2.1321

another suggestion is that from this new perspective, some previous works should be reevaluated, for they attribute the companies' good or bad results to the CEOSs leadership capacity.

In conclusion, this study opens the path for innumerous exploratory researches. This study can be continued in different manners, that is, by applying the methodology developed in this paper to smaller American companies or different economies.

\section{REFERENCES}

Alcoa Annual Report (2003). Pittsburgh: Alcoa. Anual.

Bonfaire, H., \& Sandoval, M. (2001). Introdução a Inferência Estatística. Rio de Janeiro. Sociedade Brasileira de Matemática.

Brealey, R., \& Myers, R. (2003). Principles of corporate finance. New York: McGraw Hill. 7.ed.

Casanova, M. (2005). Nada a Caminho: Impessoalidade, Niilismo e Técnica a partir do Pensamento de Martin Heidegger. Rio de Janeiro: Forense Universitária.

Matos, J. A. (2001). Theoretical Foundations of Corporate Finance. Princeton. Princeton University Press.

Gastineau, G., \& Kritzman, M. (1996). Dictionary of Financial Risk Manangement. United States of America: Frank J. Fabozzi Associates.

Goldstein, M. L. (1985). Grading the CEO. Industry Week. (224), 48-49.

Heidegger, M. (1995). Voträge und Aufsätze. Frankfurt: Vitorio Klostermann.

Ittner, C., Larcker, D., Rajam, M. (1997). The Choice of Performance Measures in Annual Bonus Contracts. The accounting Review, (72), 231-255.

Joannes. P. P. P. Ii. (1991). Encyclical Letter. Centesimus Annus. Encyclical Letter To His Venerable Brothers in the Episcopate the Priests and Deacons Families of Men and Women religious all the Christian Faithful and to all men and women of good will on the hundredth anniversary of Rerum Novarum. 1991.

Lear, R. (1999). Equality for All. Chief Executive. 18-19.

Longenecker, C., \& Gioia, D. (1988) Neglected at the top, Executives Talk About Executive Appraisal. Sloan Management Review. (40), 41-47.

Ittner, C., Larcker, D., \& Rajam, M. (1997) The Choice of Performance Measures in Annual Bonus Contracts. The accounting Review. (72), 231-255.

Newman, J. F. (2001) CEO Performance Appraisal: Review and Recommendations/ Practitioner Application. Journal of Healthcare Management. (46), 21-38.

Peters, E. (1996) Chaos and Order in the Capital Markets. A New View of Cycles, Prices and Market Volatility: New York, John Wiley \& Sons inc, 2.ed.

Silva, P. (2004). Determinants of the Anonymity of the CEO Evaluation Process. Journal of Managerial Issues, XVI(1), 87-102. 
DOI: $10.14807 /$ ijmp.v12i2.1321

Spiegel, M. (1977). Probabilidade e estatística. Trad. de Alfredo Alves de Faria. São Paulo: Makron books.

Tyler, L., BIGGS, E. (2001). Practical Governance: CEO Performance Appraisal. Trustee. (54), 18-21.

Verespej, M. A. (1994). Before It's Too Late. Industry Week. p. 11.

\section{COMPANIES' ELECTRONIC WEBSITES:}

3m. : <http://solutions.3m.com/wps/portal/_l/en_US/_s.155/121258/_s.155/121718> Access: 23th December, 2019.

Dupont. Available:

<http://www1.dupont.com/NASApp/dupontglobal/corp/index.jsp?page=/content/US/en_US/o verview/directors/holliday.html>.Access: 23th Decembe, 2019.

Coca-Cola Company . Available: <http://www2.coca-

cola.com/ourcompany/executivei.html>. Access: 28th December, 2019.

American Australian Association. Available:

<http://www.americanaustralian.org/Aboutus/patrons.php> Access: 3th Decembe, 2019.

Boing. Available: <http://www.boeing.com/corp_gov/board_directors.html>.Access: 28th

November, 2019.

Caterpilar. Available: <http://www.cat.com/cda/layout?m=37466\&x=7>.

Access: 30th November, 2019.

Citigroup. Available: <http://www.citigroup.com/citigroup/press/2002/020908a.htm. Access: 30th November, 2019.

Exxom Mobile. Available:

<http://www.exxonmobil.com/Corporate/About/OurManagement/Corp_OM_Raymond.asp>. Access: 23th November, 2019.

General Eletric. Available: <http://www.ge.com/en/company/news/immelt.htm>.Access:7th May, 2019.

General Motors. Available:

<http://www.gm.com/company/investor_information/corp_gov/bios/wagoner.htm>. Access: 6th May, 2019.

Hewllet Packard. Available: <http://www.hp.com/hpinfo/execteam/bios/fiorina.html>. Access: 6th October, 2019.

Honeywell International. Available:

<http://www.honeywell.com/sites/honeywell/bgpresident_cat1ec3d95-fb5435840f-

3e3e4447ab3472a0c2a5e5fdc1e6517d_HTM1ec3d95-fb5437b62e-

3e3e4447ab3472a0c2a5e5fdc1e6517d.htm Access: 3th October, 2019.

IBM. Available: <http://www.ibm.com/ibm/sjp/bio.shtml>. Access: 6th October, 2019.

Jonhson \& Jonhson. Available:

$<$ http://www.investor.jnj.com/governance/BioDetail.cfm?BioID=3197>. Access: 6th October, 2019.

Home Depot. Available: <http://ir.homedepot.com/leadership.cfm?BioPage=ceo>. Access: 6th October, 2019. 
DOI: 10.14807/ijmp.v12i2.1321

McDonald's corporation. Available:

$<$ http://www.mcdonalds.com/corp/about/bios/charlie_bell.html>. Access: 6th October, 2019.

Merck. Available:: <http://www.merck.com/about/management_committee/rvg.html>. Access: 6th October, 2019.

Pfizer. Available:: <http://www.pfizer.com/are/mn_investors_corporate_board.cfm>

. Access: 6th August, 2019.

Sbc Comunications. Available:: <http://www.sbc.com/gen/press-room?pid=5068>. Access: 6th August, 2019.

United Tecnologies . Available: <http://www.utc.com/profile/facts/executives/david.htm>. Access: 6th August, 2019.

Verizon. Available: <http://investor.verizon.com/corp_gov/bios/seidenberg_ivan.html>. Access: 6th August 2019.

Walt Disney Company. Available::

<http://corporate.disney.go.com/news/corporate/2004/2004_0910_letter.html>.Access: 5th August, 2019. 